\title{
A novel oil-in-water drilling mud formulated with extracts from Indian mango seed oil
}

\author{
Saket Kumar ${ }^{1} \cdot$ Aarti Thakur ${ }^{2} \cdot$ Nitesh Kumar ${ }^{3} \cdot$ Maen M. Husein ${ }^{1}$
}

Received: 29 December 2018 / Published online: 12 September 2019

(c) The Author(s) 2019

\begin{abstract}
Drilling muds with less environmental impact are highly desired over conventional diesel-based mud systems, especially in light of the emerging strict environmental laws. In this article, a novel oil-in-water $(\mathrm{O} / \mathrm{W})$ emulsion drilling fluid formulated with a methyl ester extracted from Indian mango seed oil was evaluated. The effect of the weight percent of different constituents of the emulsion/suspension including the oil phase, bentonite, and polyanionic cellulose polymer on the rheology and the fluid loss was examined. The methyl ester oil phase/mud system displayed superior physical, chemical, rheological and filtration properties relative to the diesel and the mango seed oil. Eco-toxicity of the methyl ester and diesel $(\mathrm{O} / \mathrm{W}) \mathrm{emul}-$ sion mud systems was assessed using the acute lethal concentration test. The Indian mango methyl ester $(\mathrm{O} / \mathrm{W})$ emulsion mud displayed much less impact on fish population. Flow characteristics collected from the flow model at $85{ }^{\circ} \mathrm{C}$ suggested excellent shear thinning behavior of the Indian mango methyl ester (IMME) (O/W) emulsion mud. Moreover, the IMME $(\mathrm{O} / \mathrm{W})$ emulsion displayed strong pseudoplastic behavior, an attractive feature in a drilling mud, with increasing clay content and polymer concentration. The methyl ester mud was thermally stable over a wide range of the constituent concentrations. Furthermore, a particle size analysis revealed that engineered drilling muds targeting suspension of particles with certain size range can be formulated by changing the volume fraction of the methyl ester in the mud system.
\end{abstract}

Keywords Indian mango seed oil · Fluid loss $\cdot$ Emulsion drilling mud $\cdot$ Shear thinning $\cdot$ Pseudoplastic fluid

\section{Introduction}

An emulsion is a dispersion of certain amounts of one liquid into another. Emulsions are broadly classified into oil-in-water (O/W) and water-in-oil (W/O) emulsions (Jha et al. 2018). In an $\mathrm{O} / \mathrm{W}$ emulsion, oil is the dispersed phase and water is the dispersion medium, whereas the opposite is true for W/O emulsions, also known as invert emulsions (Caenn and Chillingar 1996). By virtue of their superior properties relative to

Edited by Yan-Hua Sun

Maen M. Husein

mhusein@ucalgary.ca

Saket Kumar

itssakriti@gmail.com

1 Department of Chemical and Petroleum Engineering, The University of Calgary, Calgary, AB T2N 1N4, Canada

2 Emerson Innovation Center, Pune, Maharashtra, India

3 MDNK Oil and Gas Consultants, Mumbai, Maharashtra, India the single phase, emulsions are widely used as drilling fluids. The performance of any drilling fluid depends on its rheological properties such as apparent viscosity, plastic viscosity, yield point and gel strength (Caenn and Chillingar 1996). Aggressive oil exploration of onshore, offshore conventional and unconventional plays mandated highly performing drilling muds in challenging formations such as deep water, highsalinity, high-pressure high-temperature (HPHT), shales as well as other reservoirs (Friedheim et al. 1996; Friedheim 1997). As such, a drilling fluid cost generally accounts for 20\%-25\% of the total cost of oil well drilling (Shell Training Manual 2000). The future of drilling fluids lies in inexpensive and effective fluids under harsh conditions.

Generally, emulsion-based muds display high wellbore stabilizing capability, which is particularly important for shale formations, high lubricity, low torque and drag and contamination tolerance (Haimson et al. 2002; Yu et al. 2013). The advantages of $(\mathrm{O} / \mathrm{W})$ emulsion-based muds over water-based muds are excellent rheological and filtration properties, thermal stability as well as high tolerance to solids, salts and acid-gas contamination (Aloh et al. 2014; 
Jha et al. 2013). Moreover, the lower density of an O/W mud makes it attractive for underbalanced drilling operations (Eckhout et al. 2000), since it reduces the risk of exceeding the formation fracture pressure (Yue and Ma 2008). Diesel $(\mathrm{O} / \mathrm{W})$ emulsion drilling muds are widely used in drilling operations primarily due to their viscosity profile and low flammability (Nelson et al. 1984). Diesel (O/W) emulsion drilling muds, on the other hand, are not eco-friendly due to their high toxicity. In fact, these muds are a significant threat to terrestrial, coastal and marine habitats (Li et al. 2016a, b), especially in light of their low rates of degradation. Reports showed that the disposal of diesel oil-based emulsion muds into marine environment has been a major cause for polluting water supplies (Agwu et al. 2015a). Accordingly, environmentalists have been highly vocal in their contempt not only for the use of diesel oil but mainly for their disposal to the environment (Degouy et al. 1993). Many governments of oil-producing countries have enacted laws on offenders to protect their environment from the harmful impacts of diesel $(\mathrm{O} / \mathrm{W})$ emulsion muds and any other toxic oil-based muds (Agwu et al. 2015b). For instance, the government of the Arabia established Corporate Regulations for Offshore Drilling Operations in November 18, 1987, whose motto is to haul back all drill cuttings to onshore facilities and clean cuttings before exposing them to the sea (Khamsin 1997). In addition to their environmental impact, diesel (O/W) emulsion muds may incur high costs to the drilling operations, especially given the required cleaning step of the drill cuttings. Subsequently, an eco-friendly-based (O/W) mud represents an attractive alternative (Yassin et al. 1991).

Drilling companies have over time developed different eco-friendly $(\mathrm{O} / \mathrm{W})$ emulsion muds. For example, the Norwegian Sector of the North Sea developed vegetable oil-derived emulsion drilling fluids. The UK and Mexico followed suit and implemented vegetable oil-derived drilling fluids (Fechhelm et al. 1999). Although having better environmental acceptability, vegetable oil-derived drilling fluids suffered relatively high viscosity (Onuh et al. 2017), which negatively impacts their performance. Vegetable oils, such as Indian mango seed oil, are renewable and have high flash and fire points, low pour and cloud points, high thermal stability, low toxicity and high rate of biodegradation (Fadairo et al. 2012). Indian mango seed oil still suffers the high viscosity limitations reported for vegetable oil-derived muds (Vijay et al. 2016). Nevertheless, given the fact that Indian mango seed oil consists mainly of an ester, its viscosity can be easily reduced by the alkali transesterification process (Cai et al. 2012). In this paper, the conversion of Indian mango seed oil to methyl ester is described. The physical and chemical properties of the Indian mango methyl ester (IMME) are evaluated and compared with the conventional diesel oil. The suitability of the IMME to replace diesel as the dispersed phase within the $\mathrm{O} / \mathrm{W}$ emulsion drilling fluids is highlighted. Further, the effects of different concentrations of IMME, bentonite, and polyanionic cellulose (PAC)-LVG on the performance of the $\mathrm{O} / \mathrm{W}$ mud are detailed. Some tests including fluid loss, rheological properties, thermal stability, salt tolerance and dynamic aging are carried out as per API standards in order to assess the performance of the proposed drilling fluid. The rheological properties evaluated in this study include the apparent viscosity, the plastic viscosity, the yield point and the gel strength. Flow curves from controlled stress rheometer experiments are obtained and analyzed for varying dosages of clay and PAC at $85{ }^{\circ} \mathrm{C}$ to examine the flow behavior of the mud. Particle size analysis for the proposed IMME $(\mathrm{O} / \mathrm{W})$ emulsion mud is performed in order to evaluate its formation damage potential. Lastly, lethal concentration (LC 50) test is carried out in order to assess the eco-toxicity of the mud system.

\section{Experimental}

\subsection{Materials}

Indian mango seed oil (IMSO) was purchased from Satyanarayan oil mills (Siwan, Bihar, India). Methanol $\left(\mathrm{CH}_{3} \mathrm{OH}\right)$ and sodium hydroxide $(\mathrm{NaOH})$, which were used in the transesterification reaction to produce methyl ester from Indian mango seed oil, were purchased from SigmaAldrich (Mumbai, Maharashtra, India). Bentonite, sodium lauryl sulfate (SLS), polyanionic cellulose (low viscosity grade, $\mathrm{PAC}-\mathrm{LVG})$, sodium chloride $(\mathrm{NaCl})$ and xanthan gum (XG) used to build $\mathrm{O} / \mathrm{W}$ mud systems were all purchased from Sigma-Aldrich (Mumbai, Maharashtra, India). Rainbow fish used to evaluate the toxicity of the muds were provided by Nirma Aquatic Store (Dwarka, New Delhi, India). Diesel oil was obtained from the Institute of Drilling Technology (Institute of Drilling Technology, Oil \& Natural Gas Corporation, India). All chemicals were used as received without further purification.

\subsection{Methods}

\subsubsection{Transesterification of IMSO}

Reaction 1 represents the transesterification of Indian mango seed oil where $\mathrm{R}$ denotes a hydrocarbon chain (Naik et al. 2008). Methyl ester was produced from the transesterification of Indian mango seed oil as follows. A mass of $150 \mathrm{~g}$ of Indian mango seed oil was added to a three-necked 250$\mathrm{mL}$ round-bottom flask equipped with a reflux condenser, as shown in Fig. 1. The flask was placed on an electric heater equipped with a temperature controller and a magnetic stirrer. A mass of $1.5 \mathrm{~g}$ of the $\mathrm{NaOH}$ pellets (catalyst) was separately mixed with $45 \mathrm{~g}$ of the methanol reactant and then 


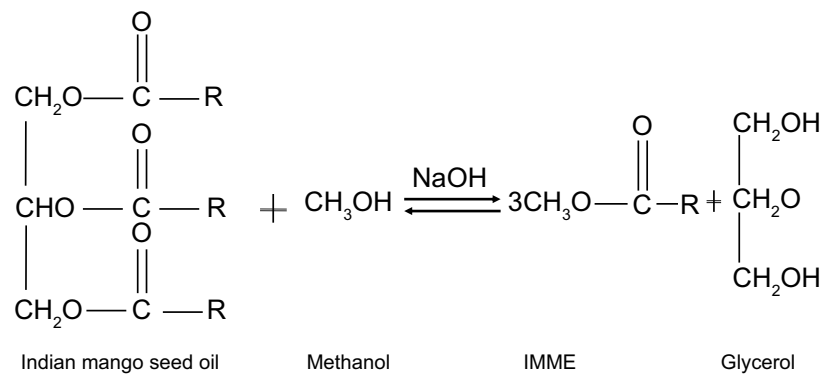

Reaction 1 Transesterification reaction for Indian mango seed oil

transferred into the round-bottom flask containing the Indian mango seed oil. The reactants were stirred at $400 \mathrm{rpm}$ and $60{ }^{\circ} \mathrm{C}$ for $50 \mathrm{~min}$.

The reaction mixture was transferred to a separatory funnel and allowed to sit for $3 \mathrm{~h}$. The lower glycerol layer was drained off by gravity, whereas the upper layer was a mixture of methanol and the IMME product (Mehulkumar et al. 2015). Vacuum distillation was used to remove methanol in excess of the reaction stoichiometry. The IMME product was further purified by washing with $1000 \mathrm{~mL}$ of hot water at $60{ }^{\circ} \mathrm{C}$ until the $\mathrm{pH}$ was reduced to 7 (Chitra et al. 2005). The water was drained off, and the IMME was heated in a hot plate to $100{ }^{\circ} \mathrm{C}$ with slow stirring for $25 \mathrm{~min}$ in order to evaporate the water. Then, the light brownish color IMME was collected and stored at room temperature.

\subsubsection{Mud preparation}

A mechanical stirrer was used to prepare $\mathrm{O} / \mathrm{W}$ emulsion muds. Two mud systems were prepared using IMME and diesel oil as follows. A mass of $10 \mathrm{~g}$ bentonite, $2.5 \mathrm{~g}$ PACLVG and $0.5 \mathrm{~g}$ XG were thoroughly mixed in $450 \mathrm{~mL}$ of water using a mechanical stirrer. Then, $1.5 \mathrm{~g}$ of SLS and $50 \mathrm{~mL}$ of IMME or diesel were added to the aqueous phase. Table 1 summarizes the amounts of the different constituents of the systems, unless otherwise stated. Other various mud compositions were prepared by varying the concentration of the oil phase (10-30 vol\%), bentonite (5-25 g), PAC-LVG $(1.5-3.5 \mathrm{~g}), \mathrm{KCl}(10-50 \mathrm{~g})$ and water in such a way that $500 \mathrm{~mL}$ of total mud was maintained for ease of comparison.

\subsection{Analysis}

The flash and fire points were estimated using a Cleveland open cup apparatus (PT-6A, Gilson Company, Ohio, USA) according to ASTM D92 standard. The cloud point and pour point were measured using a low-temperature liquid-bath apparatus (CP 610, Tannas Co. \& King Refrigeration, Inc., Texas, USA) according to ASTM D2500 and ASTM D97.

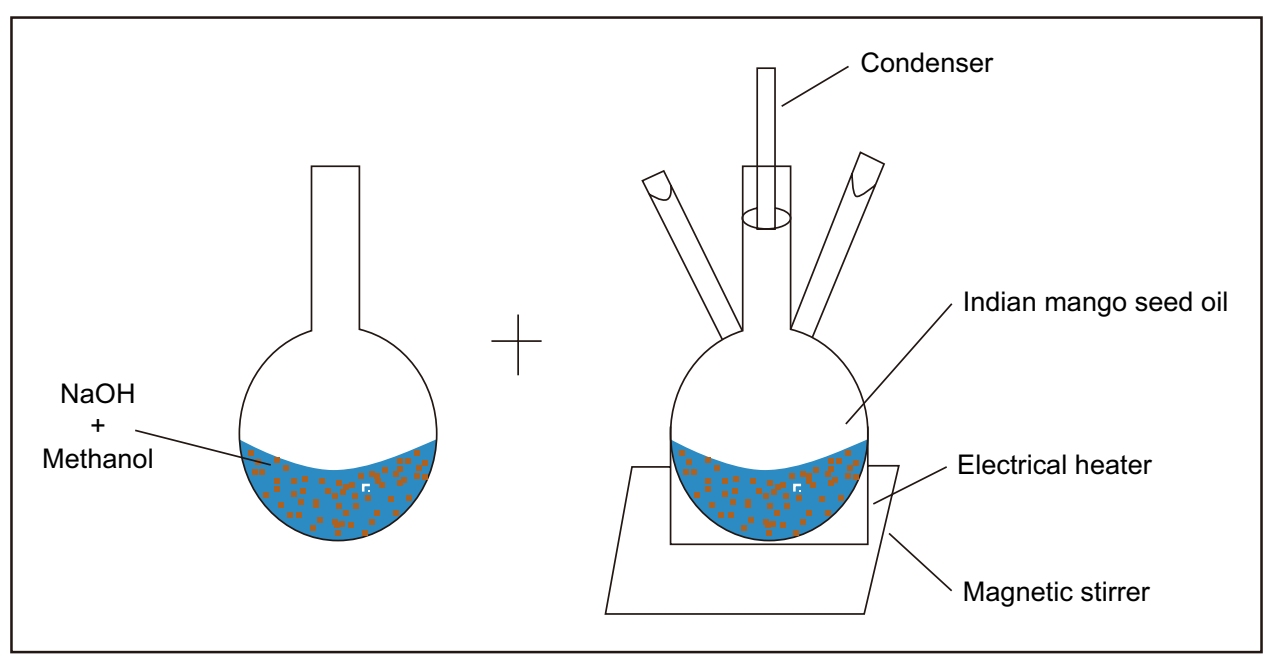

Fig. 1 A schematic drawing of the setup used to carry out alkali transesterification of Indian mango seed oil

Table 1 Compositions of $\mathrm{O} / \mathrm{W}$ emulsion drilling fluids prepared

\begin{tabular}{llllllll}
\hline $\begin{array}{l}\text { O/W emulsion drill- } \\
\text { ing fluid }\end{array}$ & Water, $\mathrm{mL}$ & Bentonite, $\mathrm{g}$ & PAC-LVG, & XG, $\mathrm{g}$ & SLS, $\mathrm{I}$ & IMME, $\mathrm{mL}$ & Diesel, $\mathrm{mL}$ \\
\hline IMME-based & 450 & 10 & 2.5 & 0.5 & 1.5 & 50 & - \\
Diesel-based & 450 & 10 & 2.5 & 0.5 & 1.5 & - & 50 \\
\hline
\end{tabular}


The dynamic viscosity and the density of Indian mango seed oil, IMME and diesel oil were determined using SVM 3001 (Anton Paar Analytical Instrument Company, Ashland, Virginia, USA) according to ASTM D7042 method.

The chemical properties such as the acid value was determined by titration following ASTM D664, the iodine value was determined by titration following AOCS Cd 1b-87, and the peroxide value was determined by titration following Cd 8b-90 (Sayyed et al. 2017). Saponification value was determined by titration following AOCS T1 1a-64, and the presence of fatty acid was inspected by a gas chromatograph (model 6850A; Hewlett Packard, USA) equipped with a flame ionization detector (Ibeto et al. 2011).

The rheological and filtration properties of drilling fluids were evaluated by a Fann viscometer (Model 35, Fann Instruments Company, Houston, Texas, USA) and the dead weight filter press apparatus (Fann Instruments Company, Houston, Texas, USA) having filter paper of $9 \mathrm{~cm}$ diameter. The flow model of the IMME $(\mathrm{O} / \mathrm{W})$ emulsion mud was confirmed by obtaining a relation between the shear stress versus the shear rate and viscosity versus shear rate on the cartesian coordinate system with the aid of Anton Paar rheometer (Anton Paar Analytical Instrument Company, Ashland, Virginia, USA) at $85^{\circ} \mathrm{C}$ (Dardir et al. 2014). The resultant curves at this temperature provided a proper understanding of the flow model of the IMME (O/W) emulsion mud at temperatures relevant to wellbore and varying shear rate (Jha et al. 2016). As part of the flow model evaluation, the mud was initially hot-rolled in an oven at $60{ }^{\circ} \mathrm{C}$ and then kept in the measuring cup of the rheometer, while the cup was fixed to the dynamic motor of the measuring system. The shear rate was maintained in the range of $1-1000 \mathrm{~s}^{-1}$.

An electrically driven roller oven equipped with an aging cell (Fann Instrument Company, Texas, USA) was used to analyze the thermal stability of the mud system at $110{ }^{\circ} \mathrm{C}$. The thermal stability of the mud was determined by dynamic aging tests. In this method, the mud was kept in an aging cell on an electrically driven roller oven for $20 \mathrm{~h}$ to simulate the borehole temperature condition as presented by Caenn et al. (2011). Again, the rheological and the filtration properties of the aged mud were determined by the API-recommended procedures. The properties of the aged samples were compared with their fresh sample counterparts in order to understand the effect of temperature on the emulsion mud.
The fixed amount of IMME (15 vol\%) in the proposed $\mathrm{O} / \mathrm{W}$ emulsion mud ( $10 \mathrm{~g}$ bentonite, $1.5 \mathrm{~g} \mathrm{SLS}, 0.5 \mathrm{~g} \mathrm{XG}$ ) and various concentrations of $\mathrm{KCl}(2.5-15 \mathrm{~g})$ were mixed together in order to analyze the tolerance of muds to salt after aging at $110{ }^{\circ} \mathrm{C}$, which is an important property to tackle the contamination issues during actual drilling operations. The effect of $\mathrm{KCl}$ salt on the rheological and filtration characteristics was analyzed using the recommended procedure by American Petroleum Institute (API).

A Malvern Mastersizer (Mastersizer 3000, Malvern Panalytical Ltd, Malvern, UK) was used to determine the particle size distribution (PSD) of the mud. PSD analysis was conducted for the different mud systems involved in this study at various concentrations of IMME. The scattered light when the laser beam passed through the samples was collected and related to PSD of the sample (Kumar et al. 2010).

Toxicity assessment was conducted on both IMME and diesel oil separately as well as the emulsion drilling mud systems. The aim for this experiment was to determine the fish mortality with the addition of IMME, diesel oil or the mud systems over a period of $6,12,18,24,30,36$ and $42 \mathrm{~h}$ (Hettiaratchi et al. 2012). First, saline water was prepared by mixing $10 \mathrm{~g}$ of $\mathrm{NaCl}$ in water to simulate seawater. A 500-mL mud consisting of $15 \mathrm{vol} \%$ IMME or diesel, $10 \mathrm{~g}$ bentonite, $2.5 \mathrm{~g}$ PAC-LVG, $1.5 \mathrm{~g}$ SLS and $0.5 \mathrm{~g} \mathrm{XG}$ was mixed with $500 \mathrm{~mL}$ of saline water to prepare diluted solutions. Initially, 10 rainbow fish were exposed to $500 \mathrm{~mL}$ of the diluted mixtures of the mud systems or pure oils for analysis of its mortality, which aids in determining the toxicity of the mud systems.

\section{Results and discussion}

\subsection{Physical properties}

The physical properties of IMME, Indian mango seed oil and diesel are summarized in Table 2. The flammability revealed that IMME and Indian mango seed oil have comparable flash and fire points, which are much higher than those of diesel oil. The flash and fire points of the oil ultimately affect the flash and fire points of the mud, which can be a matter of concern when dealing with high-temperature reservoirs. In order to reduce the likelihood of oil well fires from $\mathrm{O} / \mathrm{W}$

Table 2 Physical properties of IMME, Indian mango seed oil and diesel oil

\begin{tabular}{lllllll}
\hline Sample & Flash point, ${ }^{\circ} \mathrm{C}$ & Fire point, ${ }^{\circ} \mathrm{C}$ & Cloud point, ${ }^{\circ} \mathrm{C}$ & Pour point, ${ }^{\circ} \mathrm{C}$ & Viscosity, $\mathrm{mPa} \mathrm{s}$ & Density, g/mL \\
\hline IMME & 252 & 284 & -28 & -33 & 3.90 & 0.88 \\
$\begin{array}{l}\text { Indian mango } \\
\quad 263\end{array}$ & 283 & 4 & -9 & 39.68 & 0.91 \\
$\quad$\begin{tabular}{l} 
Siesed oil \\
\hline
\end{tabular} & 67 & 70 & 4.2 & 3.1 & 3.11 & 0.80 \\
\hline
\end{tabular}


muds, it is recommended that the fire and flash points must be above $100{ }^{\circ} \mathrm{C}$ (Naima and Liazid 2013). Lower values may contribute to the generation of hydrocarbon vapors above the mud. The US Department of Transportation specified that fuels fire and flash points of $\geq 90{ }^{\circ} \mathrm{C}$ should be treated as low fire-risk oils (Affens and Carhart 1966).

Table 2 shows lower cloud and pour points for IMME compared with Indian mango seed oil and diesel oil. O/W emulsion muds developed with diesel oil having higher pour point may suffer poor screening and excessive pressure surges in deep oil wells or other drilling operations taking place at low temperatures. Following transesterification, the pour point was significantly reduced. The pour point of IMME was $-33{ }^{\circ} \mathrm{C}$, which implies that IMME does not run into the problem of having to provide high pressures in order to overcome gel-like state produced once a liquid reaches its cloud point. The low value of pour point of IMME suggests that it can be used in a low-temperature operating environment, e.g., Arctic areas. Cloud point is essential to understand the storage stability of the oil in cold climate regions.

The viscosity of a fluid is a measure of its resistance to gradual deformation by shear stresses. During the evaluation, the dynamic viscosity was used to characterize the oils. Table 2 shows that IMME has a viscosity of $3.9 \mathrm{cP}$, which is tenfold lower than Indian mango seed oil (39.7 $\mathrm{cP})$. It is noteworthy that IMME met the API benchmark following Indian mango seed oil transesterification, which is the major objective of this study (Clark 1995). Sun et al. (2018) suggested that successful oils to replace diesel in $\mathrm{O} / \mathrm{W}$ emulsion muds should in fact have similar viscosities to diesel in order to impart the desired rheology. Oils with higher or lower viscosities may lead to different $\mathrm{O} / \mathrm{W}$ emulsion mud problems. For example, muds with high viscosity increase the required pumping pressure and limit their flow properties leading to stuck bit. Moreover, high-viscosity oils may impact the lubrication properties of the mud leading to reduced penetration rates and shorten the life of the equipment (Peng et al. 2018). Less effective lubrication of muds arises from chocking the nozzle at high mud viscosity rather than smoothly flowing into the drill bit. On the other hand, muds with low viscosity may not be able to suspend the cuttings and may be easily lost to the formation (Luheng 2014). Oils with medium viscosities (2-6 cP), such as IMME, are better suited for lubrication, circulation and cuttings suspension (Mahto and Sharma 2004).

Figure 2 shows that the viscosity of the Indian mango seed oil decreases significantly and that of the diesel decreases (to a less extent) with increasing temperatures. The high reduction in the viscosity of the mango seed oil with temperature occurs due to the induced movement of the glycerin component in the mango seed oil, which is usually the main reason for the high viscosity (Dosunmu 2018). On the other hand, IMME suffers negligible decrease

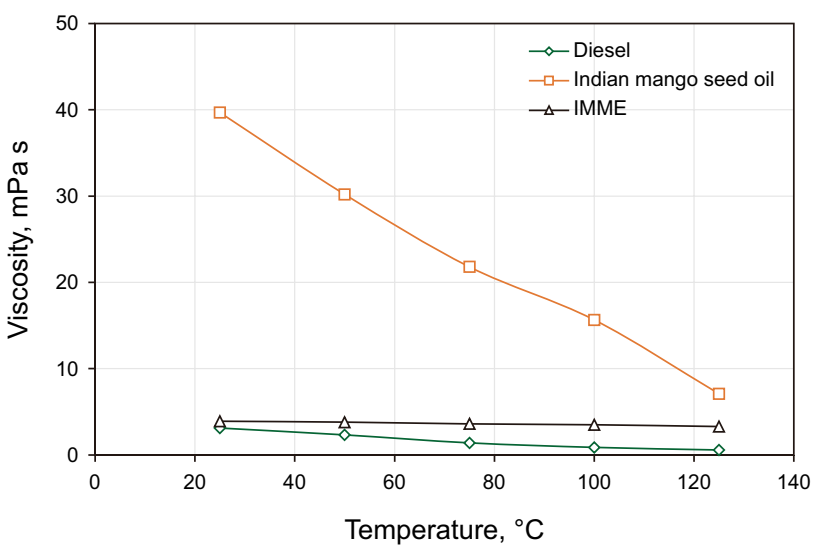

Fig. 2 Viscosities of different oil phases tested versus temperature

in viscosity up to the tested temperature of $120^{\circ} \mathrm{C}$ by virtue of separating glycerin from IMME following transesterification. The temperature-independent viscosity of the IMME is a good sign of its stability during high-temperature storage and oil well drilling.

Table 2 shows that IMME has a lower density $(0.88 \mathrm{~g} /$ $\mathrm{mL}$ ) compared with Indian mango seed oil, but still higher than diesel $(0.80 \mathrm{~g} / \mathrm{mL})$. This could be advantageous, since less weighting material may be required to adjust the density of the mud. Nevertheless, in comparison with the API standards, which specify the oil density of $0.76-0.90 \mathrm{~g} / \mathrm{mL}$ for $\mathrm{O} / \mathrm{W}$ emulsion muds, IMME appears at the higher end of the scale (Clark 1995) and may pose issues during underbalance drilling.

Overall, the physical properties of IMME suggest that IMME is a more suitable choice for the formulation of $\mathrm{O} / \mathrm{W}$ emulsion muds relative to diesel oil and Indian mango seed oil.

\subsection{Chemical properties}

The chemical properties and the fatty acid profile of the IMME and Indian mango seed oil are listed in Table 3. The acid value of IMME $(0.7 \mathrm{mg} \mathrm{KOH} / \mathrm{mg})$ is tenfold lower than that of the Indian mango seed oil, which makes it acceptable overall. This, again, suggests that transesterification is an effective route toward preparing more suited oils for O/W muds. The acid value is defined as the weight of $\mathrm{KOH}$ in $\mathrm{mg}$ required to neutralize the organic acids present in $1 \mathrm{~g}$ of oil (Kardash and Tur'yan 2005). The acid value is a measure of free fatty acids (FFA), but it also provides an indirect measure of the free glycerin obtained due to the hydrolysis of the oil (Vitz et al. 2019). An increment in FFA for IMME compared with Indian mango seed oil, as seen in Table 3, suggests hydrolysis of the triglycerides present in the oil (Kato et al. 2018). Oils having higher acid value contain more free glycerin and can cause functional problems such 
Table 3 Chemical properties of IMME and Indian mango seed oil

\begin{tabular}{|c|c|c|c|c|c|c|c|c|c|}
\hline \multirow[t]{2}{*}{ Sample } & \multirow{2}{*}{$\begin{array}{l}\text { Acid value, } \\
\mathrm{mg} \mathrm{KOH} / \mathrm{g} \text { oil }\end{array}$} & \multirow{2}{*}{$\begin{array}{l}\text { Peroxide } \\
\text { value, } \mathrm{mg} / \mathrm{g} \\
\text { oil }\end{array}$} & \multirow{2}{*}{$\begin{array}{l}\text { Iodine value, } \\
\text { mg/100 g oil }\end{array}$} & \multirow{2}{*}{$\begin{array}{l}\text { Saponification } \\
\text { value, } \mathrm{mg} \mathrm{KOH} / \mathrm{g} \\
\text { oil }\end{array}$} & \multicolumn{5}{|c|}{ Fatty acid composition } \\
\hline & & & & & Palmitic & Stearic & Oleic & Linoleic & Linolenic \\
\hline IMME & 0.70 & 2.8 & 40 & 192.5 & 6.90 & 39.77 & 45.67 & 3.28 & 4.21 \\
\hline $\begin{array}{l}\text { Indian } \\
\text { mango } \\
\text { seed oil }\end{array}$ & 7.95 & 3.2 & 44 & 196.8 & 6.62 & 38.80 & 44.20 & 3.50 & 4.25 \\
\hline
\end{tabular}

as fuel filter clogging and may later lead to reduction in the life of the mud circulation equipment (Arogba and Omede 2012). Therefore, the free glycerin obtained during hydrolysis was separated from the oil after transesterification.

Peroxide value is a measure of oxidative rancidity and oxidative degradation, i.e., oxidation stability of oils. Peroxide value is related to the long-term stability of the oil phase (Abdelazim et al. 2013). The IMME molecules are less sensitive to oxidation due to low peroxide value (Anwar et al. 2007). Although the oil stability test has not been performed in this study, Yadav et al. (2017) stated that mango methyl esters have better shelf life than many other oils. To the best of authors' knowledge, there is no standard set by any organization on the peroxide value for oils employed in O/W muds. However, Dunn (2005) reported that an increase in the peroxide value leads to a reduction in the ignition time of the oil. Hence, the lower value of peroxide is desired to reduce the likelihood of explosion or ignition during drilling operations due to lower ignition time. This renders a peroxide value for IMME of $2.8 \mathrm{mg} / \mathrm{g}$ oil more acceptable compared with Indian mango seed oil. It is worth noting that Ahmad et al. (2007) reported a peroxide value of $<10 \mathrm{mg} / \mathrm{g}$, which can be used as a guideline for fresh oil that can be safely used in such an igniting environment.

The iodine value is used to determine the unsaturated $\mathrm{C}=\mathrm{C}$ bonds of the oil and assess the stability of the oil for industrial applications. From Table 3, the iodine value for IMME is 40 and falls within the ASTM standard for vegetable oils used to formulate O/W muds (Michael et al. 2009). Accordingly, Indian mango seed oil is not be suited as an oil phase for $\mathrm{O} / \mathrm{W}$ muds and may not be stable toward oxidation (ASTM Standard Manual 2003). Higher iodine values may lead to oil thickening and gum formation, which directly impact the rheology of the drilling fluids (Mehulkumar et al. 2015).
Lastly, the saponification value for IMME (192.5 mg $\mathrm{KOH} / \mathrm{g}$ oil) suggests a very high content of low molecular weight organic molecules.

The chemical composition of IMME fatty acids collected from gas chromatography (GC) indicates that they are primarily composed of steric and oleic acids and to a lesser extent palmitic, linoleic and linolenic acids. Similar composition is recorded for Indian mango seed oil, as shown in Table 3 (Sayyed et al. 2017). The high content of saturated fatty acids, e.g., stearic acid, is a good sign of chemical stability, whereas unsaturated fatty acids contribute reactive double bonds.

The elemental analysis and the paraffin, olefin and aromatic analysis of diesel, as provided by Oil and Natural Gas Corporation (ONGC), a national oil company of India, are listed in Table 4 for comparison. Montagnolli et al. (2015) stated that diesel is not easily biodegraded and toxic, by virtue of its content of paraffins and aromatics. However, esters are less toxic and biodegradable (Li et al. 2016b). Accordingly, the use of IMME may lead to much less environmental footprint relative to diesel oil.

The physicochemical properties of IMME, Indian mango seed oil and diesel suggest that IMME should serve as a great alternative to diesel as the oil phase for the preparation of $\mathrm{O} / \mathrm{W}$ emulsion mud systems.

\subsection{Rheological and filtration studies}

\subsubsection{Effect of IMME and diesel on the rheological and filtration properties of the $\mathrm{O} / \mathrm{W}$ emulsion mud}

The rheological and filtration parameters for the IMME and diesel (O/W) emulsion muds are depicted in Fig. 3. It can be seen from the results that IMME has a significant effect on rheological properties of the mud. Plastic

Table 4 Chemical composition of diesel oil

\begin{tabular}{lllllll}
\hline Oil & \multicolumn{2}{l}{ Elemental composition, $\%$} & & \multicolumn{2}{l}{ Chemical composition, \% } \\
\cline { 2 - 3 } & Carbon & Hydrogen & Sulfur & & Aromatics & Paraffin \\
\hline Diesel & 85.58 & 13.82 & 0.037 & 36.50 & 60.70 & Olefins \\
\hline
\end{tabular}




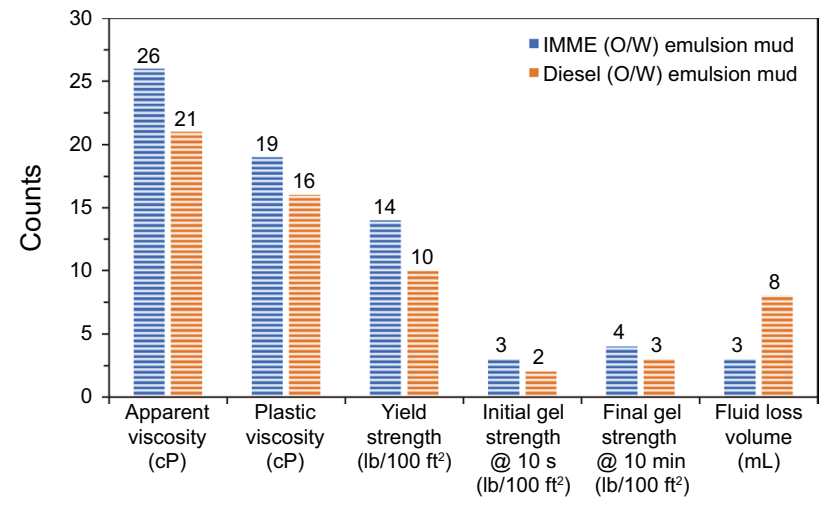

Fig. 3 Rheological and filtration properties of IMME and diesel $(\mathrm{O} / \mathrm{W})$ emulsion muds

viscosity (PV) represents the viscosity of a mud at difference between the dial reading at $600 \mathrm{rpm}$ and $300 \mathrm{rpm}$, whereas the apparent viscosity of the mud is measured at specified shear rate as per API standard, i.e., one half of the dial reading (shear rate) at $600 \mathrm{rpm}$ (Anawe et al. 2018). In a borehole, certain values of PV are desired to enable the drilling fluid to circulate the rock cuttings to the surface at different shear rates. However, when the operational pump stops, the apparent viscosity is the one which provides viscous gelation to the mud to restrict the slippage of the rock cuttings toward the drilling bit (Liang et al. 2016). The apparent viscosity, plastic viscosity and yield strength for the IMME (O/W) emulsion muds were $5 \%-15 \%$ higher than those for the diesel $(\mathrm{O} / \mathrm{W})$ emulsion muds. It has been reported that a mud system with a viscosity ranging from 18 to $30 \mathrm{cP}$ has shown better holecleaning tendency (Paswan et al. 2016). On the other hand, the high apparent viscosity of the IMME $(\mathrm{O} / \mathrm{W})$ emulsion mud system $(>35 \mathrm{cP})$ may lead to higher pumping power, formation fracturing and increased risk of lost circulation. The yield point for varying IMME concentration in the proposed $\mathrm{O} / \mathrm{W}$ emulsion mud falls in an acceptable range as per API standard (Sulaimon et al. 2017). During circulation, if an operation stops for some operational reason, the gel strength and the yield point are key variables to suspending the cuttings from accumulating behind the drill bit. Nevertheless, high value of yield point leads to larger frictional pressure loss inside the wellbore and high circulation power to restart circulation (Crespo et al. 2012). More than $50 \%$ reduction in the fluid loss was obtained with IMME $(\mathrm{O} / \mathrm{W})$ emulsion mud $(3 \mathrm{~mL})$ relative to the diesel-based mud $(8 \mathrm{~mL})$, which is advantageous especially when drilling through sensitive formations. Drilling fluids may invade the formation leading to significant formation damage (Deville et al. 2011). It is noted, nevertheless, that the improved filtration performance of
IMME-based emulsion mud could have resulted from its higher apparent viscosity.

The effect of the volume fraction of IMME and diesel from 10 to $30 \mathrm{vol} \%$ in the $\mathrm{O} / \mathrm{W}$ emulsion mud on the rheological and filtration properties of the mud is presented in Figs. 4, 5, 6. API specifications for drilling fluids are listed in Table 5. The IMME $(\mathrm{O} / \mathrm{W})$ emulsion mud displays properties which meet the requirement of API. For example, the plastic viscosity varies from 19 to $30 \mathrm{cP}$ and the yield point varies from 14 to $32 \mathrm{lb} / 100 \mathrm{ft}^{2}$, which is higher than the conventionally used diesel $(\mathrm{O} / \mathrm{W})$ emulsion muds at the same composition. The enhanced rheological parameters for the IMME $(\mathrm{O} / \mathrm{W})$ emulsion mud give it a role of a rheology modifier in a mud system (William et al. 2014). The fluid loss also falls in an acceptable range $(3-3.5 \mathrm{~mL}$ ) for the IMME $(\mathrm{O} / \mathrm{W})$ emulsion mud. On the other hand, a high fluid loss was reported for the diesel $(\mathrm{O} / \mathrm{W})$ emulsion mud, which increases the environmental risk of its use. The lower fluid

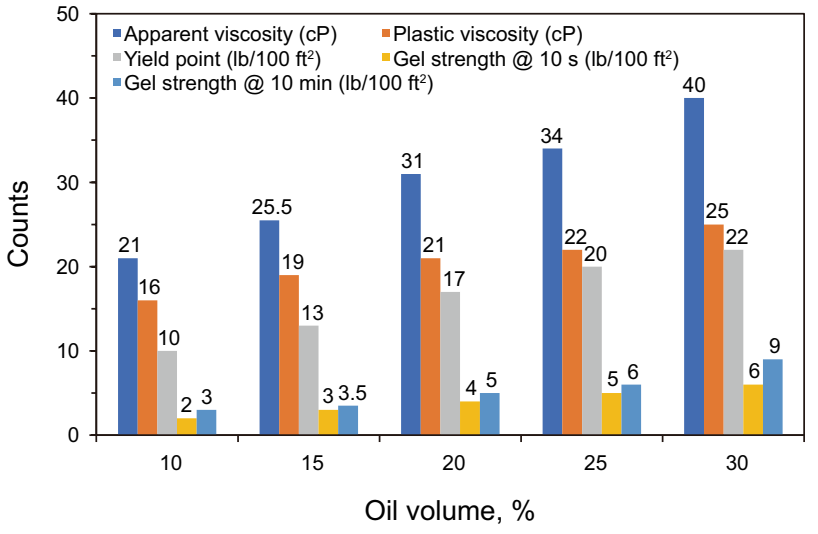

Fig. 4 Effect of different compositions of diesel in the diesel (O/W) emulsion muds on the rheological parameters of the mud. Other constituents: $10 \mathrm{~g}$ bentonite, $2.5 \mathrm{~g}$ PAC-LVG, $0.5 \mathrm{~g} \mathrm{XG}$, and $1.5 \mathrm{~g}$ SLS

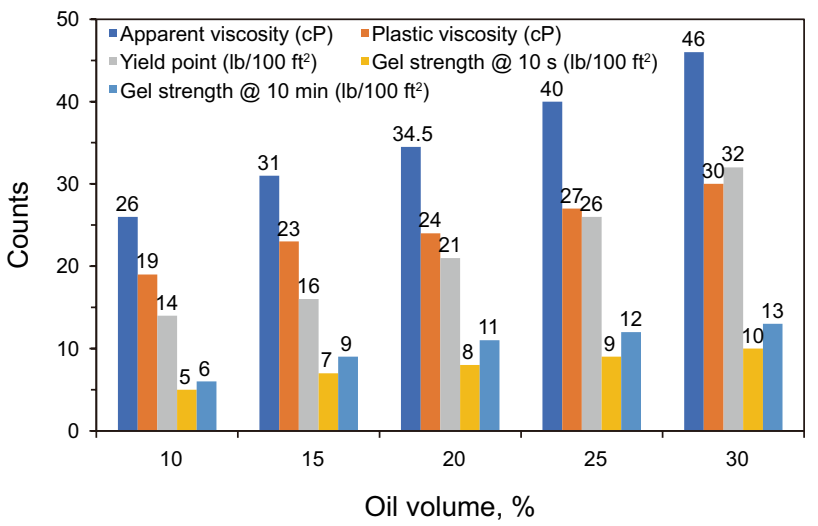

Fig. 5 Effect of different compositions of IMME in the IMME (O/W) emulsion muds on the rheological parameters of the mud. Other constituents: $10 \mathrm{~g}$ bentonite, $2.5 \mathrm{~g}$ PAC-LVG, $0.5 \mathrm{~g} \mathrm{XG}$ and $1.5 \mathrm{~g}$ SLS 


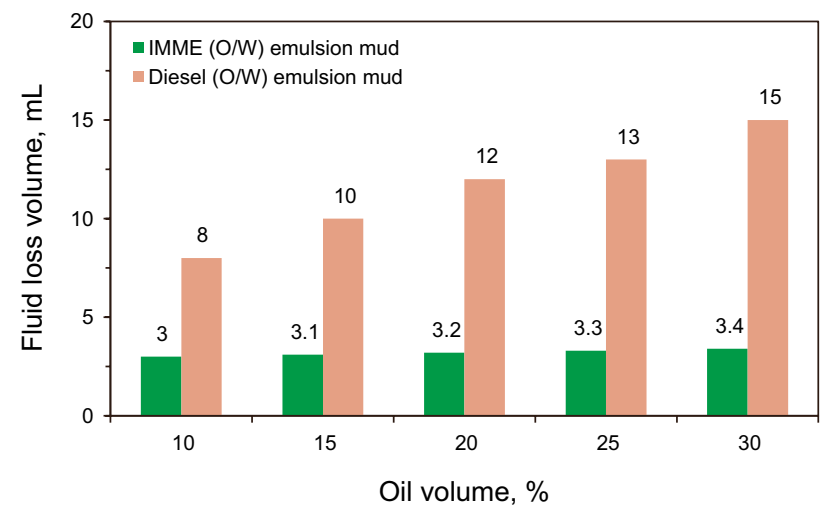

Fig. 6 Effect of different compositions of IMME/diesel in the IMME/ diesel $(\mathrm{O} / \mathrm{W})$ emulsion muds on the filtration properties of the mud. Other constituents: $10 \mathrm{~g}$ bentonite, $2.5 \mathrm{~g}$ PAC-LVG, $0.5 \mathrm{~g} \mathrm{XG}$, and $1.5 \mathrm{~g} \mathrm{SLS}$

Table 5 API specification for the drilling mud

\begin{tabular}{lllll}
\hline $\begin{array}{l}\text { Plastic viscos- } \\
\text { ity, cP }\end{array}$ & $\begin{array}{l}\text { Yield point, } \\
\mathrm{lb} / 100 \mathrm{ft}^{2}\end{array}$ & $\begin{array}{l}\text { Gel strength, } \\
\mathrm{lb} / 100 \mathrm{ft}^{2}\end{array}$ & $\begin{array}{l}\text { Fluid loss } \\
\text { volume, } \mathrm{mL}\end{array}$ \\
\cline { 3 - 4 } & $10 \mathrm{~s}$ & $10 \mathrm{~min}$ & \\
\hline$<35$ & $15-25$ & $6-10$ & $8-12$ & $<4$ \\
\hline
\end{tabular}

loss observed for the IMME (O/W) emulsion mud may be attributed to a better interaction with other mud constituents, in addition to the higher viscosity of the oil phase and its plug effect (Jain et al. 2015). The plug effect may be stated as squeezing of oil into the pores to plug it, which accelerates the filter cake forming tendency of the mud on the borehole wall surface (Jha et al. 2013).

Overall, and aside from the advantage of using an environmentally benign oil, the rheological and filtration properties of the IMME $(\mathrm{O} / \mathrm{W})$ emulsion mud fall within recommended optimum values for an $\mathrm{O} / \mathrm{W}$ emulsion drilling fluid (Sulaimon et al. 2017) and are superior to those of the diesel $(\mathrm{O} / \mathrm{W})$ emulsion mud. As such, better hole cleaning and low mud invasion into formation are expected.

\subsubsection{Effect of bentonite on the rheological and filtration properties of the IMME $(0 / W)$ emulsion mud}

The effect of the amount of bentonite from 5 to $25 \mathrm{~g}$ on the rheological and filtration properties of the mud, at constant values of all the other variables, is reported in Fig. 7. High amounts of the clay increased the viscosity of the mud due to more friction/interaction between the clay particles (William et al. 2014). The results show that the apparent viscosity increased from 23 to $41 \mathrm{cP}$, the plastic viscosity increased from 16 to $30 \mathrm{cP}$, and the yield point increased from 14 to $26.0 \mathrm{lb} / 100 \mathrm{ft}^{2}$. Nevertheless, all of these values are within

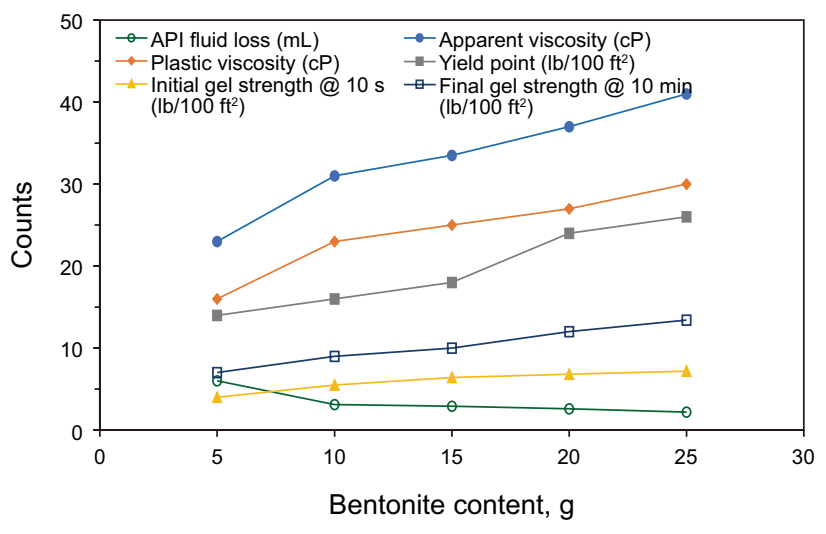

Fig. 7 Effect of bentonite loading on the rheological and filtration properties of the IMME $(\mathrm{O} / \mathrm{W})$ emulsion mud. Other constituents: $15 \mathrm{vol} \%$ IMME, $2.5 \mathrm{~g}$ PAC-LVG, $0.5 \mathrm{~g} \mathrm{XG}$, and $1.5 \mathrm{~g}$ SLS

acceptable ranges (Alizadeh and Ehsan 2019) and help tuning the drilling mud properties for different tasks. For example, a high gel strength is desired in order to suspend drill cuttings when the fluid is stagnant (Jain and Mahto 2017). The increase in the value of these parameters is attributed to an increase in the electrochemical interactions in the mud with higher clay content (Jain et al. 2015).

The fluid loss was reduced to $2.2 \mathrm{~mL}$ from $6 \mathrm{~mL}$ for the proposed IMME $(\mathrm{O} / \mathrm{W})$ emulsion mud system with increasing bentonite content. The lower value of the fluid loss may also be attributed to the effective plugging of the finely emulsified and uniform oil droplets (Li et al. 2016c), which arise from the stability of the IMME $(\mathrm{O} / \mathrm{W})$ emulsion. In addition, the presence of bentonite enhances the mud cake formation tendency by virtue of its better adsorption and flocculation during the buildup of the filter cake (KoK 2010; Jain et al. 2015). Low fluid loss is desired in order to restrict the physicochemical interaction inside the borehole which may lead to wellbore instability issues (Kumar et al. 2018).

\subsubsection{Effect of PAC-LVG on the rheological and filtration properties of the IMME $(\mathrm{O} / \mathrm{W})$ emulsion mud}

The effect of increasing the amount of PAC-LVG in the IMME $(\mathrm{O} / \mathrm{W})$ emulsion mud from 1.5 to $3.5 \mathrm{~g}$ on the rheological and fluid loss properties of the mud is depicted in Fig. 8. The plastic viscosity increased from 14.0 to $29.0 \mathrm{cP}$, the apparent viscosity increased from 24.0 to $36.0 \mathrm{cP}$, and the yield point increased from 10.0 to $23.0 \mathrm{lb} / 100 \mathrm{ft}^{2}$. PACLVG adsorbs on the clay particles leading to higher rates of flocculation (Kumar et al. 2017), which in turn may lead to higher values of the rheological properties. Adsorption of the polymer on clay platelets and the subsequent flocculation also increase the gel strength and thixotropy of the IMME (O/W) emulsion mud (Zakaria et al. 2012). At a 


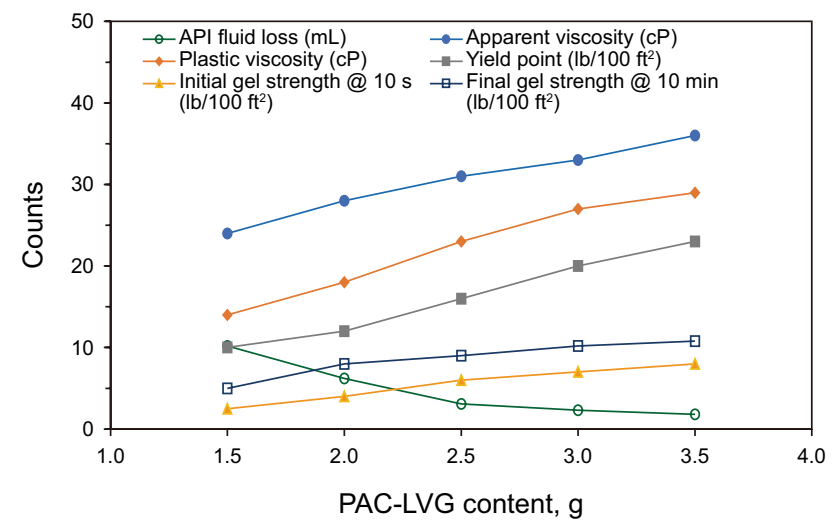

Fig. 8 Effect of PAC-LVG on the rheological and filtration properties of the IMME (O/W) emulsion muds. Other constituents: 15 vol\% IMME, $10 \mathrm{~g}$ bentonite, $0.5 \mathrm{~g} \mathrm{XG}$, and $1.5 \mathrm{~g}$ SLS

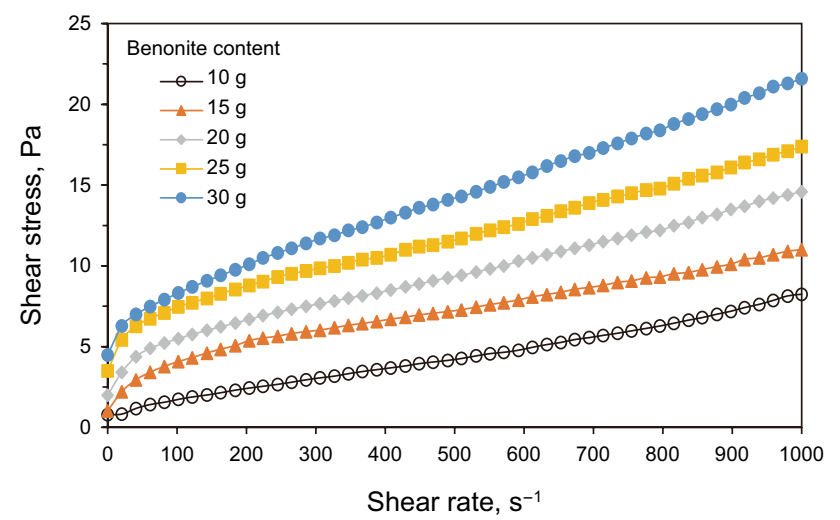

Fig. 9 Effect of the amount of bentonite in the IMME (O/W) emulsion mud on shear stress versus shear rate profile. Other variables: 15 vol\% IMME, 2.5 g PAC-LVG, $1.5 \mathrm{~g}$ SLS, $0.5 \mathrm{~g}$ XG

high concentration of PAC-LVG polymer, along with other additives, the fluid loss decreased. The polymer works as a crosslinker among clay particles leading to the formation of a more compact filter cake (Sarapardeh et al. 2018).

\subsection{Flow behavior studies}

The flow behavior curves of the IMME (O/W) emulsion muds are depicted in Figs. 9, 10, 11 and 12 for different amounts of bentonite and PAC-LVG. Figures 9 and 10 reflect a Bingham plastic fluid, described by Eq. (1), with increases in the bentonite and the PAC-LVG concentrations (Jha et al. 2013). The yield stress increased with an increase in the bentonite content likely due to the higher degree of swelling of clay platelets. At the zero shear rate and when approaching the yield stress, the links between clay platelets and PAC molecules increase with an increase in the volume fraction

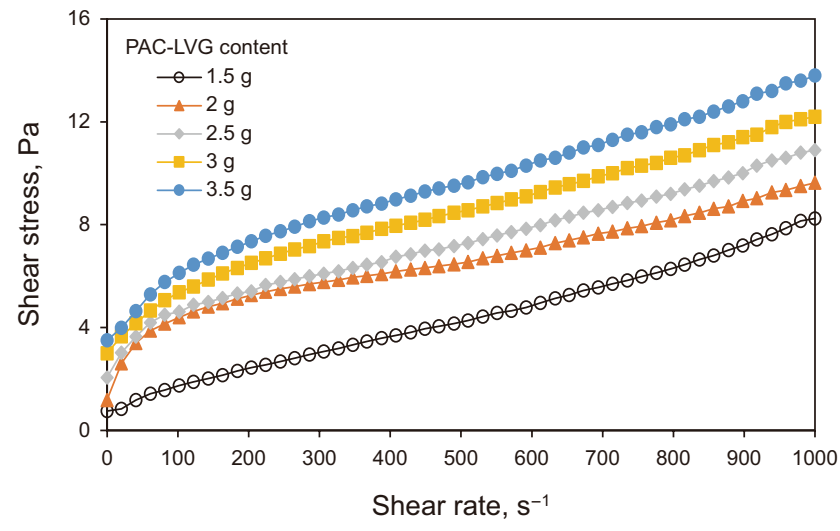

Fig. 10 Effect of the amount of PAC-LVG in the IMME (O/W) emulsion mud on shear stress versus shear rate profile. Other variables: $15 \mathrm{vol} \%$ IMME, $10 \mathrm{~g}$ bentonite, $1.5 \mathrm{~g}$ SLS, $0.5 \mathrm{~g} \mathrm{XG}$

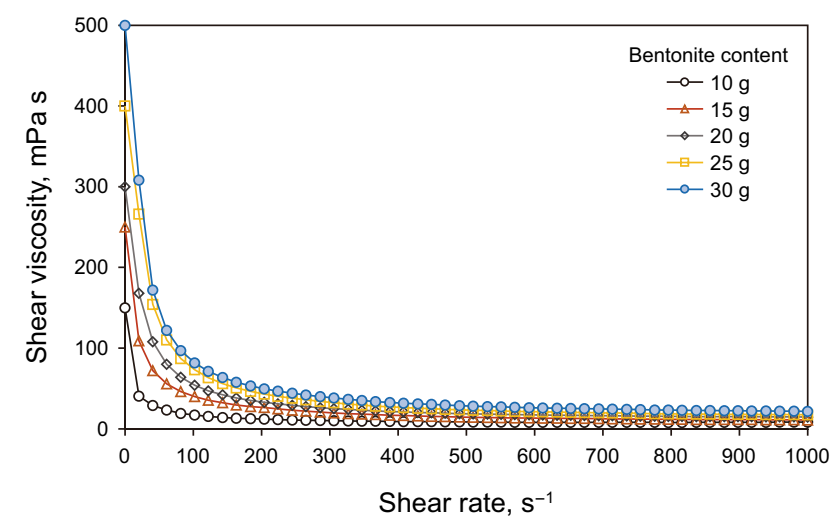

Fig. 11 Effect of the amount of bentonite in the IMME (O/W) emulsion mud on viscosity versus shear rate profile. Other variables: 15 vol\% IMME, $2.5 \mathrm{~g}$ PAC-LVG, $1.5 \mathrm{~g}$ SLS, $0.5 \mathrm{~g} \mathrm{XG}$

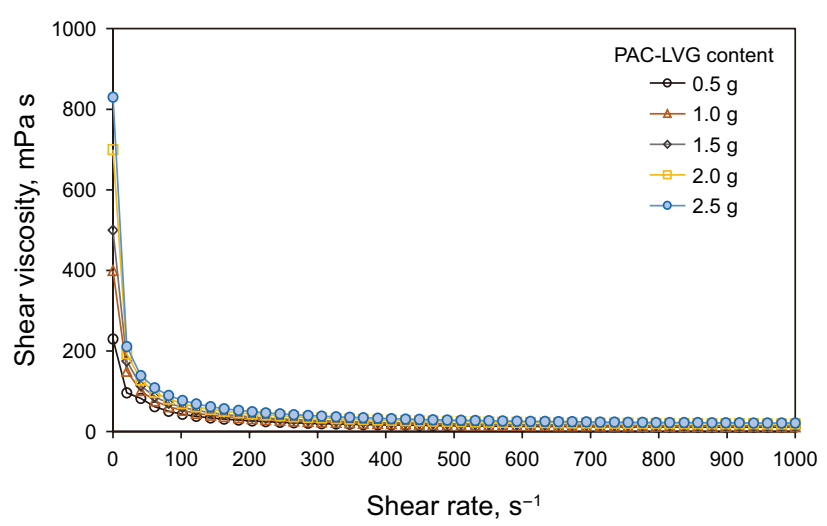

Fig. 12 Effect of the amount of PAC-LVG in the IMME (O/W) emulsion mud on viscosity versus shear rate profile. Other variables: 15 vol\% IMME, $10 \mathrm{~g}$ bentonite, $1.5 \mathrm{~g}$ SLS, $0.5 \mathrm{~g} \mathrm{XG}$ 
of the oil phase in the mud due to thermal and electrolytic effects, which ultimately lead to swelling of clay platelets and adsorption of polymer molecules (Jain and Mahto 2017). This swelling and adsorption enhance the rheology of the IMME (O/W) emulsion mud (Paswan et al. 2016). The Bingham plastic model helps predicting the thixotropic and gelling tendency of the mud. As stated earlier, the gel strength governs the cuttings suspension tendency of the mud. The yield stress, on the other hand, governs the stress required to break the gelation of the mud and enables mud circulation once the operation resumes.

$\tau=\tau_{\mathrm{y}}+\gamma(\mu)$

where $\tau$ is the shear stress, $\tau_{\mathrm{y}}$ is the yield stress, $\gamma$ is the shear rate, and $\mu$ is the plastic viscosity. The plastic viscosity is the slope of the straight line passing through the linear region of the plot, and yield point $\left(\tau_{\mathrm{y}}\right)$ is the threshold stress or the minimum stress required by the mud to flow, which is obtained from Figs. 9 and 10 at $\gamma=0$.

Figures 11 and 12 show the effect of the amounts of bentonite and PAC-LVG on the shear viscosity of the fluid, which decreases with increasing shear rate. The reason for the decrease in shear viscosity with increasing shear rate is due to charge shielding effect which causes the PAC-LVG chains to coil up into spherical coils and thus minimize the surface exposed to water. Thus, the reduction in interaction between PAC-LVG chains and clay leads to a decrease in viscosity with increasing shear rate. Also, the PAC-LVG chains hydrate poorly, and the effective size of the molecules of swollen polymer decreases (Rojas et al. 2018; Assi et al. 2018).

Shear thinning behavior, or pseudoplastic behavior, is associated with a mud system where the shear stress increases with the shear rate, coupled with a decrease in the shear viscosity (Jha et al. 2016), as described in Figs. 9, 10,11 and 12. This shear thinning property is desirable for the drilling muds which are subjected to different shearing, and it is essential for their role in hole cleaning at different shear rate conditions (Jha et al. 2013). During mixing and pumping the mud inside the borehole, the mud with low viscosity is desired, and vice versa for back circulation of the mud from the borehole to the surface with rock cuttings (Anawe et al. 2018).

\subsection{Thermal stability of the $(0 / \mathrm{W})$ emulsion mud systems}

The thermal stability of the mud was evaluated for $500-\mathrm{mL}$ mud systems having the following composition $15 \mathrm{vol} \%$ IMME or diesel, $10 \mathrm{~g}$ bentonite, $2.5 \mathrm{~g}$ PAC-LVG, $0.5 \mathrm{~g} \mathrm{XG}$ and $1.5 \mathrm{~g}$ SLS. The results in Table 6 show that aging did not significantly affect the rheological properties of the IMME $(\mathrm{O} / \mathrm{W})$ emulsion mud, as opposed to $\operatorname{diesel}(\mathrm{O} / \mathrm{W})$ emulsion mud, up to $110^{\circ} \mathrm{C}$, likely due to the thermal resistance of the IMME (Jha et al. 2013). A decrease in viscosity is typically experienced at lower temperatures than at $80{ }^{\circ} \mathrm{C}$ due to the degradation of polymer and the flocculation of clay particles (Paswan et al. 2016).

\subsection{Salt tolerance property of the $(0 / \mathrm{W})$ emulsion mud systems}

The effect of $\mathrm{KCl}$ concentration on the rheological and filtration characteristics of the proposed $\mathrm{O} / \mathrm{W}$ emulsion drilling fluids is described in Fig. 13. The observation shows that rheological and filtration parameters were not affected significantly. However, the rheological parameters like apparent viscosity and yield point decreased slightly

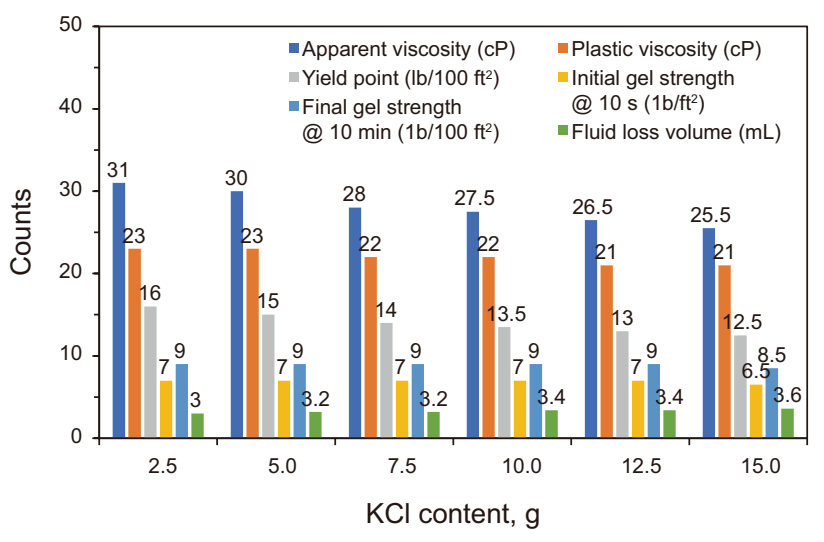

Fig. 13 Effect of salt $(\mathrm{KCl})$ concentration on the rheological and filtration properties of the IMME $(\mathrm{O} / \mathrm{W})$ emulsion mud. Other constituents: 15 vol\% IMME, $2.5 \mathrm{~g}$ PAC-LVG, $0.5 \mathrm{~g} \mathrm{XG}$, and $1.5 \mathrm{~g} \mathrm{SLS}$

Table 6 Effect of aging on the rheological properties of the IMME and diesel (O/W) emulsion mud systems at $110{ }^{\circ} \mathrm{C}$ for $20 \mathrm{~h}$

\begin{tabular}{llllllll}
\hline Mud system & Treatment & $\begin{array}{l}\text { Apparent } \\
\text { viscosity, } \mathrm{cP}\end{array}$ & $\begin{array}{l}\text { Plastic } \\
\text { viscosity, } \\
\mathrm{cP}\end{array}$ & $\begin{array}{l}\text { Yield point, } \\
\mathrm{lb} / 100 \mathrm{ft}^{2}\end{array}$ & $\begin{array}{l}\text { Initial gel strength } \\
\text { at } 10 \mathrm{~s}, \mathrm{lb} / 100 \mathrm{ft}^{2}\end{array}$ & $\begin{array}{l}\text { Final gel strength at } \\
10 \mathrm{~min}, \mathrm{lb} / 100 \mathrm{ft}^{2}\end{array}$ & $\begin{array}{l}\text { Fluid loss } \\
\text { volume, } \mathrm{mL}^{2}\end{array}$ \\
\hline IMME-based (O/W) mud & Before aging & 31.0 & 23 & 16 & 7 & 9.0 & 3.5 \\
& After aging & 30.5 & 23 & 15 & 6 & 3.5 & 2.9 \\
Diesel (O/W) emulsion mud & Before aging & 25.5 & 19 & 13 & 3 & 2.5 & 8.0 \\
& After aging & 19 & 14 & 9 & 2 & & 11.0 \\
\hline
\end{tabular}


at higher salt concentration in the IMME (O/W) emulsion mud. The reason for lowering of apparent viscosity $(31.0-25.5 \mathrm{cP})$ and yield point $\left(16-12.5 \mathrm{lb} / 100 \mathrm{ft}^{2}\right)$ was due to the addition of $\mathrm{KCl}$ which reduces the separation of clay platelets also known as flocculation and reduces the hydration and expansion of PAC-LVG (Balaban et al. 2015). In addition, the fluid loss (3-3.6 mL) also increased slightly with an increase in the salt concentration in the proposed $(\mathrm{O} / \mathrm{W})$ emulsion mud. The reason for the increase in fluid loss was due to sticking of clay platelets, i.e., de-flocculation and poor hydration of PACLVG, which has slightly reduced the efficiency of the mud to form a filter cake on the borehole wall surface (Jain et al. 2015). Moreover, these tests have shown a significant degree of tolerance of the proposed IMME (O/W) emulsion mud toward contaminants like salts, i.e., $\mathrm{KCl}$ which suits their applicability in actual well conditions (Paswan et al. 2016).
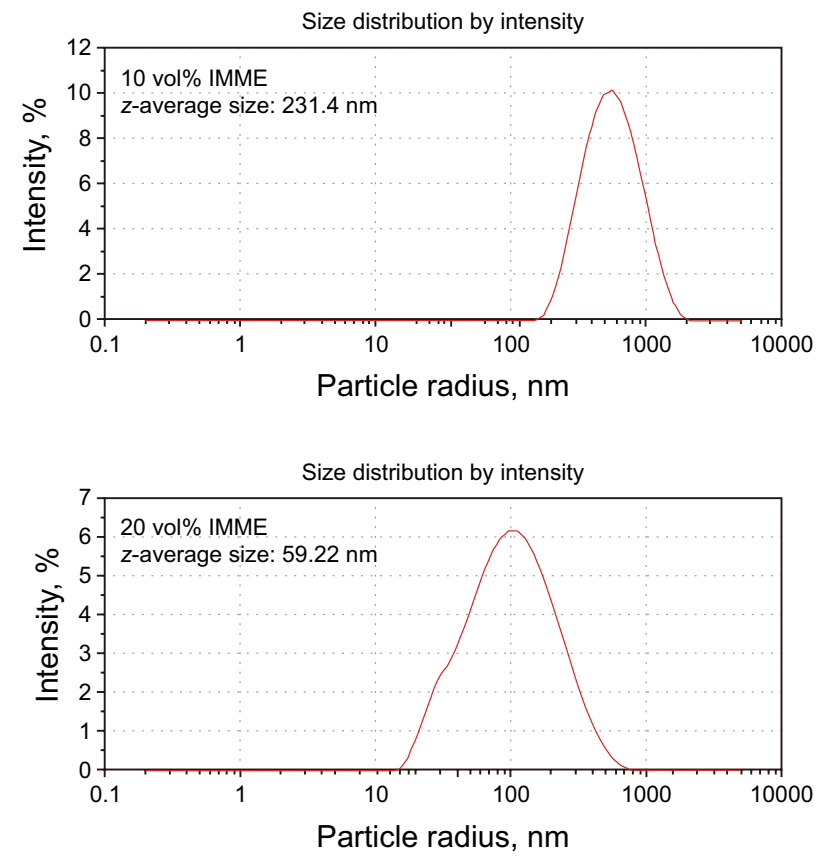

\subsection{Particle size distribution of the IMME (O/W) emulsion mud}

The variation of PSD in response to the volume fraction of IMME is given in Fig. 14. The figure shows that the particle size ( $z$-average size) decreases with an increase in the volume fraction of IMME from $10 \mathrm{vol} \%$ to $30 \mathrm{vol} \%$. $z$-average size is the ratio of harmonic intensity to the weighted arithmetic average particle diameter (Mahto and Sharma 2004). At 10 vol\%, the $z$-average size (i.e., mean radius) is $231.4 \mathrm{~nm}$ and it decreased to $40.3 \mathrm{~nm}$ when the volume fraction of IMME increased to $30 \mathrm{vol} \%$. The proper selection of the diameter of the loss circulation materials (LCM) of a mud relative to the pore throat of the formation helps in building up an effective filter cake that reduces fluid loss to the formation (Jha et al. 2013; Abrams 1977). If particles in the mud system are not bridging the pores quickly to form a filter cake, then spurt loss will be high and will
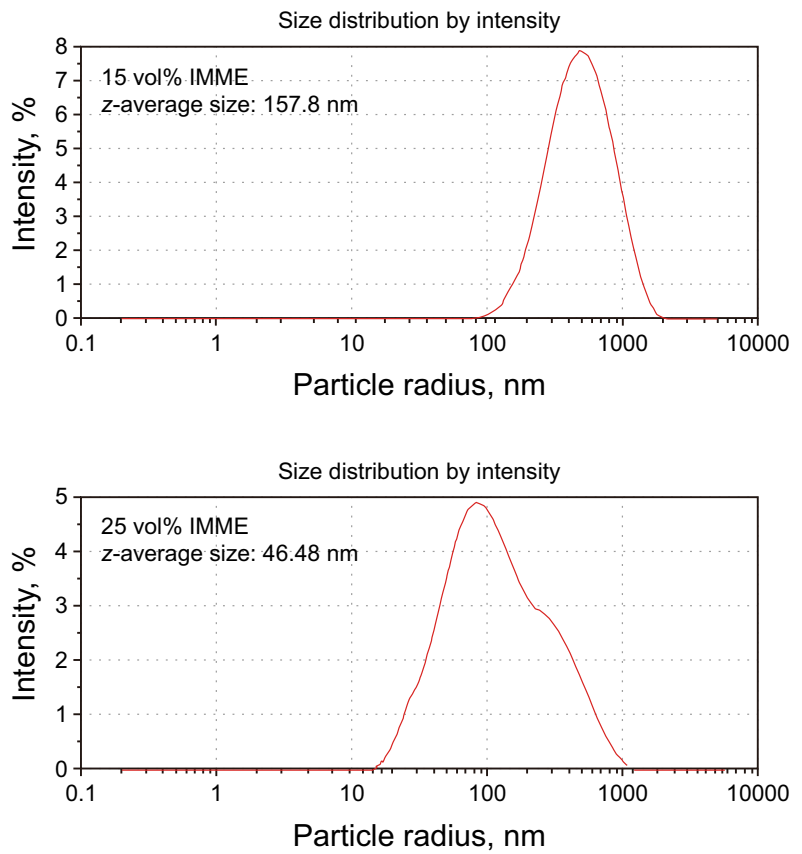

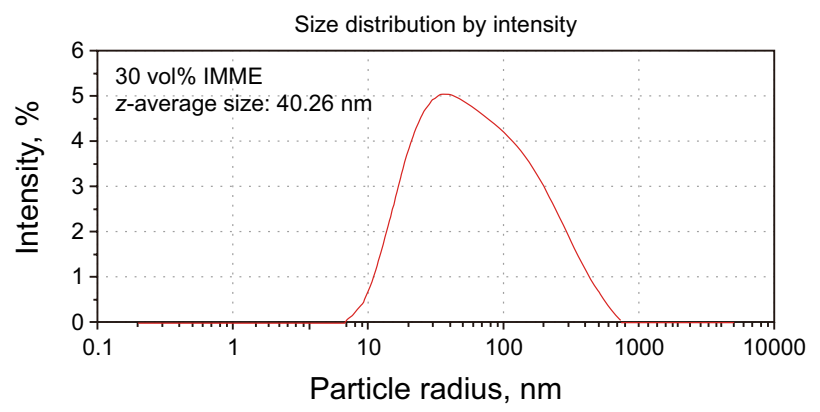

Fig. 14 Effect of volume fraction of IMME (from 10 to 30 vol\%) in the IMME (O/W) emulsion mud on the PSD of clay particles suspended in the mud. Other variables: 500-mL mud system, $10 \mathrm{~g}$ bentonite, $2.5 \mathrm{~g}$ PAC-LVG, $1.5 \mathrm{~g}$ SLS and $0.5 \mathrm{~g}$ XG 


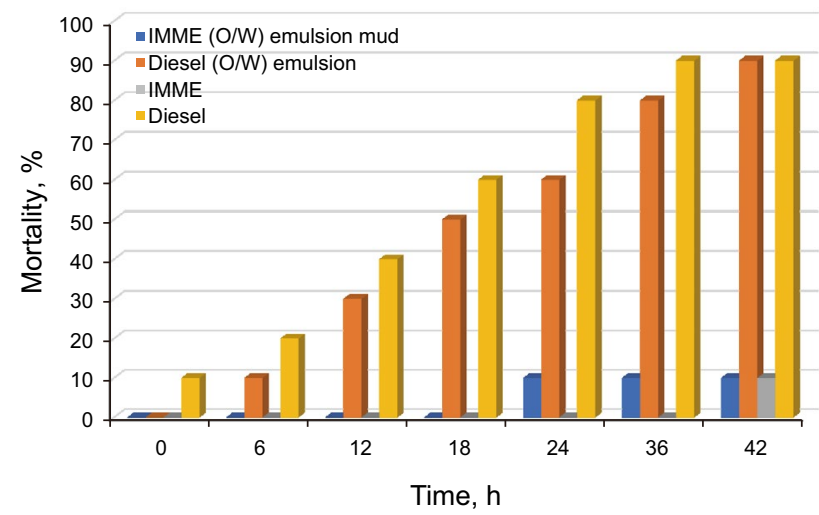

Fig. 15 Comparison of the acute lethal concentration (ALC) between IMME and diesel $(\mathrm{O} / \mathrm{W})$ emulsion muds. Dilution ratio with saline water, $D=0.5,500 \mathrm{~mL}$ mud, $15 \mathrm{vol} \%$ IMME or diesel in the $(\mathrm{O} / \mathrm{W})$ emulsion mud, $10 \mathrm{~g}$ bentonite, $2.5 \mathrm{~g}$ PAC-LVG, $1.5 \mathrm{~g}$ SLS and $0.5 \mathrm{~g}$ XG

damage the formation (Jain et al. 2015). Kumar et al. (2018) reported that the majority of wellbore instability occurs due to fluid loss and rock fluid interaction. Thus, it is evident that engineered drilling fluids can be designed to suspend particles within certain range that are best suited for a given formation.

\subsection{Toxicity assessment of the $0 / \mathrm{W}$ emulsion mud systems}

The toxicity of the IMME, diesel, and IMME and diesel $(\mathrm{O} / \mathrm{W})$ emulsion muds was compared for a dilution ratio, $D=0.5$, as calculated from Eq. (2). Ten rainbow fish were exposed to each prepared diluted solution, and observations of fish mortality were made every $6 \mathrm{~h}$. The results for the mortality test are depicted in Fig. 15, where the percent mortality (\%) values were calculated from Eq. 3.

$D=\frac{V_{\mathrm{m}}}{V_{\mathrm{m}}+V_{\mathrm{s}}}$

$M=\left(N_{\mathrm{f}}-N_{\mathrm{fa}}\right) \times 100 \%$

where $D$ is the dilution ratio; $V_{\mathrm{m}}$ is the volume of the mud; $V_{\mathrm{s}}$ is the volume of the saline water; $M$ is the mortality; $N_{\mathrm{f}}$ is the number of rainbow fish initially used for the test; and $N_{\mathrm{fa}}$ is the number of rainbow fish found alive at the given time.

Based on the LC50 toxicity test, the mud formulated with IMME is deemed more environmentally friendly when exposed to marine life (aquatic animals and plants). It was observed that more than $90 \%$ of the fish population survived the test after $42 \mathrm{~h}$, whereas $M<20 \%$ of the fish population survived the diesel $(\mathrm{O} / \mathrm{W})$ emulsion mud. Generally, the $\mathrm{O} / \mathrm{W}$ emulsion mud systems had a lower impact on fish mortality than the oil phase.

\section{Conclusions}

This work developed an eco-friendly $\mathrm{O} / \mathrm{W}$ emulsion mud system formulated from a methyl ester extract from Indian mango seed oil. The major challenge associated with vegetable oil $(\mathrm{O} / \mathrm{W})$ emulsion drilling muds, namely their high viscosity, was addressed through transesterification of the oil. Major conclusions from this work are drawn as follows.

- The methyl ester, IMME, displayed superior physical and chemical properties relative to diesel and the parent mango seed oil including flash, fire, cloud and pour points, viscosity, density as well as acid, peroxide, iodine and saponification values.

- The viscosity of the IMME was within acceptable range for an $\mathrm{O} / \mathrm{W}$ emulsion mud and was temperature independent up to $120^{\circ} \mathrm{C}$.

- The different physical properties of the IMME, and more importantly the pour point, make the fluid well suited for drilling in cold environments, e.g., deep water and Arctic area.

- The IMME $(\mathrm{O} / \mathrm{W})$ emulsion mud displayed superior rheological and filtration properties and met all API benchmarks for drilling fluids at different constituent concentrations tested in this study. Increasing the additive loading in the IMME $(\mathrm{O} / \mathrm{W})$ emulsion mud, e.g., bentonite and PAC-LVG, significantly lowered the fluid loss, which makes the mud suitable for drilling sensitive formation such as shales.

- The flow curves plotted as shear stress versus shear rate for the IMME $(\mathrm{O} / \mathrm{W})$ emulsion mud reflects its pseudoplastic rheology, which well suits drilling fluid functions. Moreover, the gel strength, yield point and plastic viscosity were found appropriate to suspend cuttings during operation as well as during stagnation and recirculation.

- The dynamic aging tests revealed that the IMME $(\mathrm{O} / \mathrm{W})$ emulsion mud is stable up to $110^{\circ} \mathrm{C}$.

- Particles with different size ranges could be suspended by manipulating the volume fraction of the IMME oil in the mud. This enables engineering mud systems optimized to reduce filtration loss in certain formations and to cope the formation damage risk which is even more sensitive in challenging reservoirs like shales.

- The lethal concentration (LC50) test results suggest that the IMME $(\mathrm{O} / \mathrm{W})$ emulsion mud as well as IMME oil has lower toxicity compared with the traditionally used diesel.

Acknowledgements The authors would like to acknowledge DIT University, Dehradun, India, for providing laboratory facilities and support. The authors would also like to acknowledge Schulich School of Engineering, The University of Calgary, for their support. 
Open Access This article is distributed under the terms of the Creative Commons Attribution 4.0 International License (http://creativeco mmons.org/licenses/by/4.0/), which permits unrestricted use, distribution, and reproduction in any medium, provided you give appropriate credit to the original author(s) and the source, provide a link to the Creative Commons license, and indicate if changes were made.

\section{References}

Abdelazim AA, Mahmoud A, Ramadan-Hassanien MF. Oxidative stability of vegetable oils as affected by sesame extracts during accelerated oxidative storage. J Food Sci Technol. 2013;50(5):868-78. https://doi.org/10.1007/s13197-011-0419-8.

Abrams A. Mud design to minimize rock impairment due to particle invasion. J Pet Technol. 1977;29(5):586-92. https://doi. org/10.2118/5713-PA.

Affens WA, Carhart HW. The effect of ullage on the flash point and lower flammability limit temperatures of jp-5 jet fuels. Memorandum report. Naval Research Laboratory; 1966.

Agwu OE, Isemin IA, Akpabio MG. Cost benefit analysis of vegetable oils used as alternatives to diesel in the formulation of oil-based drilling muds. In: SPE Nigeria annual international conference and exhibition, 4-6 August, Lagos, Nigeria; 2015a. https://doi. org/10.2118/178265-MS.

Agwu OE, Anietie NO, Francis DU. A comparative study of diesel oil and soybean oil as oil-based drilling mud. J Pet Eng. 2015b;2015, 828451. https://doi.org/10.1155/2015/828451.

Ahmad S, Ashraf SM, Zafar F. Development of linseed oil based polyesteramide without organic solvent at lower temperature. J Appl Polym Sci. 2007;104(2):1143-8. https://doi.org/10.1002/ app. 25774.

Alizadeh A, Ehsan K. Experimental investigation of the oil based Aphron drilling fluid for determining the most stable fluid formulation. J Pet Sci Eng. 2019;174:525-32. https://doi.org/10.1016/j. petrol.2018.11.065.

Aloh S, Obeagu G, Emmanuel I, Christian EO. Extraction and partial characterization of Mustard seed oil. World J Pharm Res. 2014;4:177-95.

Anawe A, Paul L, Folayan JA. Novel synthetic-based drilling fluid through enzymatic interesterification of Canola oil. Int J Chem Eng. 2018;2018, 6418090. https://doi.org/10.1155/2018/6418090.

Anwar F, Hussain AI, Iqbal S, Bhanger MI. Enhancement of the oxidative stability of some vegetable oils by blending with Moringa oleifera oil. Food Chem. 2007;103(4):1181-91. https://doi. org/10.1016/j.foodchem.2006.10.023.

Arogba SS, Omede A. Comparative antioxidant activity of processed Mango (Mangifera indica) and Bush Mango (Irvingia gabonensis) kernels. Niger Food J. 2012;30(2):17-21. https://doi.org/10.1016/ S0189-7241(15)30029-1.

Assi A, Khazeem R, Salem A, Ali A. Studying the effects of different polymers on rheological properties of water base muds. J Eng. 2018;24(12):12-25. https://doi.org/10.31026/j.eng.2018.12.02.

ASTM Standard Manual; 2003.

Balaban RDC, Vidal ELF, Borges MR. Design of experiments to evaluate clay swelling inhibition by different combinations of organic compounds and inorganic salts for application in water base drilling fluids. Appl Clay Sci. 2015;105-106:124-30. https://doi. org/10.1016/j.clay.2014.12.029.

Caenn R, Chillingar GV. Drilling fluids: state of the art. J Pet Sci Eng. 1996;14(3-4):221-30. https://doi.org/10.1016/09204105(95)00051-8.

Caenn R, Darley HCH, Gray GR. Composition and properties of drilling and completion fluids. Houston: Gulf Professional Publishing; 2011. eBook ISBN: 9780123838599.
Cai S, Xuan Z, Jiangbo C, Hui Y, Cuijuan Z. Transesterification reaction reduce the viscosity of vegetable insulating oil. In: International conference on high voltage engineering and application, Shanghai; 2012. https://doi.org/10.1109/ichve.2012.6357102.

Chitra P, Venkatachalam P, Sampathrajan A. Optimization of experimental conditions for biodiesel production from alkali-catalyzed transesterification of Jatropha curcus oil. Energy Sustain Dev. 2005;9(3):13-18. https://doi.org/10.1016/S0973-0826(08)60518 $-9$.

Clark PE. Drilling mud rheology and the API recommended measurements. In: SPE production operations symposium, 2-4 April, Oklahoma City, Oklahoma; 1995. https://doi.org/10.2118/29543 -MS.

Crespo FE, Ahmed RM, Saasen A, Enfis M, Amani M. Surgeand-swab pressure predictions for yield-power-law drilling fluids. SPE Drill Complet. 2012;27:585-874. https://doi. org/10.2118/138938-PA.

Dardir MM, Ibrahime S, Soliman M, Desouky SD, Hafiz AA. Preparation and evaluation of some esteramides as syntheticbased drilling fluids. Egypt J Pet. 2014;23:35-43. https://doi. org/10.1016/j.ejpe.2014.02.006.

Degouy D, Argillier J-F, Demoulin A. biodegradable muds: an attractive answer to environmental legislations around offshore drilling. In: Offshore European conference, Aberdeen, 7-10 September; 1993. https://doi.org/10.2118/26737-MS.

Deville JP, Fritz B, Jarrett M. Development of water-based drilling fluids customized for shale reservoirs. SPE Drill Complet. 2011;26(04):484-91. https://doi.org/10.2118/140868-PA.

Dosunmu A. Development of environmentally friendly oil based mud using palm-oil and groundnut-oil. In: Nigeria annual international conference and exhibition, 31 July-7 August, TinapaCalabar, Nigeria; 2018. https://doi.org/10.2118/140720-MS.

Dunn RO. Oxidative stability of soybean oil fatty acid methyl esters by oil stability index (OSI). J Am Oil Chem Soc. 2005;82(5):381-7. https://doi.org/10.1007/s11746-005-1081-6.

Eckhout D, Dolan S, Gogan R. Development process and field applications of a new ester-based mud system for ERD wells on Australia's Northwest Shelf. In: IADC/SPE Asia Pacific drilling technology, Kuala Lumpur, 11-13 September; 2000. https://doi. org/10.2118/62791-MS.

Fadairo AA, Adeyemi GA, Ameloko A, Ogidigbo E, Airende O. Environmental impact evaluation of a safe drilling mud. In: SPE middle east health, safety, security, and environment conference and exhibition, 2-4 April, Abu Dhabi, UAE; 2012. https://doi. org/10.2118/152865-MS.

Fechhelm RG, Gallaway BJ, Farmer JM. Deepwater sampling at a synthetic drilling mud discharge site on the outer continental shelf, Northern Gulf of Mexico. In: SPE/EPA exploration and production environmental conference, 1-3 March, Austin, Texas; 1999. https://doi.org/10.2118/52744-MS.

Friedheim JE. Second-generation synthetic drilling fluids. J Pet Technol. 1997;49(07):724-8. https://doi.org/10.2118/38251 -JPT.

Friedheim JE, Conn HL. Second generation synthetic fluids in the North Sea: are they better? In: SPE/IADC drilling conference, 12-15 March, New Orleans, Louisiana; 1996. https://doi. org/10.2118/35061-MS.

Haimson BC, Chang CD. True triaxial strength of the KTB amphibolite under borehole wall conditions and its use to estimate the maximum horizontal in situ stress. J Geophys Res Solid Earth. 2002;107(B10):ETG 15-1-14. https://doi.org/10.1029/2001J B000647.

Hettiaratchi J, Sil A, Wakadikar K, Kumar S, Satheesh BS, Sivagami $\mathrm{S}$, et al. Toxicity characteristics of drilling mud and its effect on aquatic fish populations. J Hazard Toxic Radioact Waste 
Manag. 2012;15:51-7. https://doi.org/10.1061/(ASCE)HZ.21535515.0000092.

Ibeto CN, Ofoefule AU, Ezeugwu HC. Fuel quality assessment of biodiesel produced from groundnut oil (Arachis hypogea) and its blend with petroleum diesel. Am J Food Technol. 2011;6:798 803. https://doi.org/10.3923/ajft.2011.798.803.

Jain R, Mahto V. Formulation of a water-based drilling fluid system with synthesized graft copolymer for troublesome shale formations. J Nat Gas Sci Eng. 2017;38:171-81. https://doi. org/10.1016/j.jngse.2016.12.018.

Jain R, Paswan B, Mahto T, Mahto V. Study the effect of synthesized graft copolymer on the inhibitive water-based drilling fluid system. Egypt J Pet. 2015;26:875-83. https://doi.org/10.1016/j. ejpe.2015.03.016.

Jha PK, Mahto V, Saxena VK. Study the rheological and filtration properties of an oil-in-water emulsion for its application in oil and gas well drilling. J Pet Eng Technol. 2013;3:25-30. https:// doi.org/10.1007/s13367-018-0013-y.

Jha PK, Mahto V, Saxena VK. Development of emulsion based drilling fluid system for depleted fractured reservoirs. Int J Chemtech Res. 2016;6:146-52. https://doi.org/10.17491/cgsi/2016/95907.

Jha PK, Mahto V, Saxena V. Study the effect of polymers on the stability and rheological properties of oil-in-water $(\mathrm{O} / \mathrm{W})$ Pickering emulsion muds. Korea Aust Rheol J. 2018;30:127-36. https://doi. org/10.1007/s13367-018-0013-y.

Kardash E, Tur'yan YI. Acid value determination in vegetable oils by indirect titration in aqueous-alcohol media. Croat Chem Acta. 2005;78(1):99-103.

Kato S, Shimizu N, Hanzawa Y, Otoki Y, Ito J, Kimura F, et al. Determination of triacylglycerol oxidation mechanisms in canola oil using liquid chromatography-tandem mass spectrometry. NPJ Sci Food. 2018;2(1):1. https://doi.org/10.1038/s41538-017-0009-x.

Khamsin SA. Environmental regulations for drilling operations in Saudi Arabia. In: SPE/IADC middle east drilling technology conference, 23-25 November, Bahrain; 1997. https://doi. org/10.2118/39256-MS.

Kok MV. Characterization and development of drilling fluid type for an oil field. Energy Sources. 2010;32:395-9. https://doi. org/10.1080/15567030801909433.

Kumar SS, Singh DN, Phadke RC. Methodology for determining particle- size distribution characteristics of fly ashes. Mater Civ Eng ASCE. 2010;22:435-42. https://doi.org/10.1061/(asce)mt.19435533.0000042 .

Kumar S, Jain R, Chaudhary P, Mahto V. Development of inhibitive water based drilling fluid system with synthesized graft copolymer for reactive Indian shale formation. In: SPE oil and gas India conference and exhibition, Mumbai, India, 4-6 April; 2017. https ://doi.org/10.2118/185346-MS

Kumar N, Kumar A, Kumar S. Effect of synthesized AMPS-g-clay/ $\mathrm{CuO}$ nanocomposite on WBDFS for challenging formations. In: SPE/IADC Pacific drilling technology conference, Bangkok, Thailand, 29 Aug; 2018. https://doi.org/10.2118/191105-MS.

Li S, Osisanya S, Haroun M. Development of new smart drilling fluids using nano-materials for unconventional reservoirs. In: Abu Dhabi international petroleum exhibition and conference, Abu Dhabi, UAE, 7-10 November; 2016a. https://doi.org/10.2118/18350 9-MS.

Li W, Zhao X, Ji Y, Peng H, Chen B, Liu L, et al. Investigation of biodiesel-based drilling fluid, part 1: biodiesel evaluation, invertemulsion properties, and development of a novel emulsifier package. SPE J. 2016b;21(05):1755-66. https://doi.org/10.2118/18091 8-PA.

Li W, Zhao X, Peng H, Guo J, Ji T, Chen B, et al. A novel environmentally friendly lubricant for water-based drilling fluids as a new application of biodiesel. In: IADC/SPE Asia Pacific drilling technology conference, 22-24 August, Singapore; 2016c. https:// doi.org/10.2118/180565-MS.

Liang W, Chen ZX, Sun MC, Yu WH, Li JJ. Study and application of drilling fluid for the complex deep wells in Qingxi area. Adv Pet Explor Dev. 2016;23:47-50.

Luheng Q. The application of polymer mud system in drilling engineering. Procedia Eng. 2014;73:230-6. https://doi.org/10.1016/j. proeng.2014.06.192.

Mahto V, Sharma VP. Rheological study of a water-based oil well drilling fluid. J Pet Sci Eng. 2004;145:123-8. https://doi.org/10.1016/j. petrol.2004.03.008.

Mehulkumar L, Savaliya BK, Dhorajiya D, Bharatkumar Z. Current trends in separation and purification of fatty acid methyl ester. Sep Purif Rev. 2015;44:28-40. https://doi.org/10.1080/15422 119.2013.872126.

Michael P, Jelinski C, Schick D, Whittaker K. Compatibility and filterability of hydraulic fluids. In: SAE technical paper 200901-2851; 2009. https://doi.org/10.4271/2009-01-2851.

Montagnolli RN, Lopes PRM, Bidoia ED. Screening the toxicity and biodegradability of petroleum hydrocarbons by a rapid colorimetric method. Arch Environ Contam Toxicol. 2015;68:342. https://doi.org/10.1007/s00244-014-0112-9.

Naik N, Meher LC, Naik SN, Das LM. Production of biodiesel from high free fatty acid Karanja (Pongamia pinnata) oil. Biomass Bioenergy. 2008;32(4):354-7. https://doi.org/10.1016/j.biomb ioe.2007.10.006.

Naima K, Liazid A. Waste oils as alternative fuel for diesel engine: a review. J Pet Technol Altern Fuels. 2013;4(3):30-43. https:// doi.org/10.5897/JPTAF12.026.

Nelson DW, Liu SL, Sommers LE. Extractability and plant uptake of trace elements from drilling fluids. J Environ Qual. 1984;13:562-6. https://doi.org/10.2134/jeq1984.0047242500 $1300040011 x$.

Onuh C, Dosunmu A, Anawe P, Efeovbokhan V, Adebisi A. Transesterification of non-edible vegetable oil for lubricant applications in water-based mud: a review. Int J Appl Eng Res. 2017;12(18):7397-401.

Paswan BK, Jain R, Sharma S, Mahto V, Sharma VP. Development of Jatropha oil-in-water emulsion drilling mud system. J Pet Sci Eng. 2016;144:10-8. https://doi.org/10.1016/j.petrol.2016.03.002.

Peng Y, Steel R, Olariu C. Amazon fluid mud impact on tide- and wave-dominated Pliocene lobes of the Orinoco Delta. Mar Geol. 2018;406:57-71. https://doi.org/10.1016/j.margeo.2018.08.009.

Rojas LMC, Sarapardeh AH, Husein MM, Dong M, Maini BB. Rheological behavior of surface modified silica nanoparticles dispersed in partially hydrolyzed polyacrylamide and xanthan gum solutions: experimental measurements, mechanistic understanding, and model development. Energy Fuels. 2018;32:10628-38. https ://doi.org/10.1021/acs.energyfuels.8b02658.

Sarapardeh AH, Varamesh A, Husein MM, Karan K. On the evaluation of the viscosity of nanofluid systems: modeling and data assessment. Renew Sustain Energy Rev. 2018;81:313-29. https://doi. org/10.1016/j.rser.2017.07.049.

Sayyed S, Kale R, Deshmukh S. Effects of thermal, physical, and chemical properties of biodiesel and diesel blends. Am J Mech Ind Eng. 2017;2:24-31. https://doi.org/10.11648/j.ajmie.20170201.14.

Shell Training Manual. Shell Petroleum Development Company; 2000.

Sulaimon A, Bamikole A, Adeyemi J, Rahimi M. Performance enhancement of selected vegetable oil as base fluid for drilling HPHT formation. J Pet Sci Eng. 2017;152:49-59. https://doi. org/10.1016/j.petrol.2017.02.006.

Sun J, Huang X, Jiang G, Lyu K, Liu J, Dai Z. Development of key additives for organoclay-free oil-based drilling mud and system performance evaluation. Pet Explor Dev. 2018;45(4):7640769. https://doi.org/10.1016/S1876-3804(18)30079-X. 
Vijay V, Pimm SL, Jenkins CN, Smith SJ. The impacts of oil palm on recent deforestation and biodiversity loss. PLoS ONE. 2016. https ://doi.org/10.1371/journal.pone.0159668.

Vitz E, Moore JW, Shorb J, Resina XP, Wendorff T, Hahn A. Foods: acid value and the quality of fats and oils. 6 5. 2019. https:// chem.libretexts.org/Bookshelves/General_Chemistry/Book\%3A_ ChemPRIME_(Moore_et_al.)/14Ionic_Equilibria_in_Aqueous_ Solutions/14.09\%3A_Titration_Curves/Foods\%3A_Acid_Value _and_the_Quality_of_Fats_and_Oilss. Accessed 31 Aug 2019.

William JKM, Ponmani S, Samuel R. Effect of $\mathrm{CuO}$ and $\mathrm{ZnO}$ nanofluids in xanthan gum on thermal, electrical, and high-pressure rheology of water-based drilling fluids. J Pet Sci Eng. 2014;117:15-27. https://doi.org/10.1016/j.petrol.2014.03.005.

Yadav K, Garg N, Verma A, Kumar S, Trivedi M. Optimization and extraction of oil from mango seed kernel (Mangifera Indica).
Indian J Agric Sci. 2017;87:943-6. https://doi.org/10.1051/ ocl/2017041.

Yassin AAM, Kamis A, Abdullah MO. Formulation of an environmentally safe oil based drilling fluid. In: SPE Asia-Pacific conference 4-7 November, Perth, Australia; 1991. https://doi. org/10.2118/23001-MS.

$\mathrm{Yu}$ B, Yan C, Nie Z. Chemical effect on wellbore instability of Nahr Umr Shale. Sci World J. 2013. https://doi.org/10.1155/2013/931034.

Yue Q, Ma B. Development and applications of solids-free oil-in-water drilling fluids. Pet Sci. 2008;5(2):153-8. https://doi.org/10.1007/ s12182-008-0023-3.

Zakaria M, Husein MM, Harland G. Novel nanoparticle-based drilling fluid with improved characteristics. In: SPE international oilfield nanotechnology conference and exhibition, Noordwijk, Netherlands, 12-14 June; 2012. https://doi.org/10.2118/156992-MS. 